\title{
PROSES DEPROTEINISASI KARET ALAM (DPNR) DARI LATEKS Hevea brasiliensis Muell Arg.DENGAN CARA ENZIMATIK
}

\section{DEPROTEINIZATION OF NATURAL RUBBER (DPNR) FROM LATEX OF HeVea brasiliensis Muell Arg. WITH ENZYMATIC METHOD}

Dewi Astrid ${ }^{1}$, Inky Febrianti ${ }^{1}$, Rita Mulyasari ${ }^{1}$, Ade Sholeh Hidayat ${ }^{2}$, Ace T. Hidayat ${ }^{1}$, Saadah Diana Rachman $^{1}$, Iman P. Maksum $^{1}$, Iman Rahayu $^{1} \&$ R. Ukun MS Soedjanaatmadja ${ }^{1 *}$

${ }^{1}$ Jurusan Kimia FMIPA Unpad, Jl. Raya Bandung-Sumedang Km 21 Jatinangor

${ }^{2}$ Pusat Teknologi Industri Proses- Badan Pengkajian dan Penerapan Teknologi (BPPT)-Jakarta

*Alamat korespondensi: ukun_28@unpad.ac.id \& ukun_28@yahoo.com

ABSTRAK: Indonesia merupakan salah satu negara penghasil karet terbesar setelah Thailand. Sehubungan dengan produksi karet alam di Indonesia, kultur tanaman Hevea brasiliensis secara ekonomi sangat penting bagi negara tropis penghasil karet. Salah satu peluang dari pemanfaatan lateks $H$. brasiliensis adalah dengan memproduksi karet densitas rendah yang memiliki kadar protein yang rendah untuk digunakan sebagai bahan pembuatan sponge untuk pipa apung lepas pantai atau sarung tangan, alat kontrasepsi (kondom), dan lain-lain. Tujuan dari penelitian ini adalah untuk menghasilkan karet alam yang memiliki densitas rendah, serta kandungan nitrogen total yang rendah,melalui sentrifugasi dan proses deproteinisasi dengan penambahan enzim protease(papain)dan kombinasi denaturan ( $\beta$-merkaptoetanol dan SDS) pada fraksi karet dari lateks $H$. brasilliensis Muell Arg. Klon PR 255. Lateks disentrifugasi pada suhu $0{ }^{\circ} \mathrm{C}$ dengan kecepatan $4.000 \mathrm{rpm}$ selama 180 menit dan $19.000 \mathrm{rpm}$ selama 60 menit. Lateks akan terpisah menjadi tiga fraksi utama; yaitu fraksi karet (atas), C serum (tengah) dan partikel koloid (bawah). Fraksi karet diperlakukan dengan tiga variasi enzimatik. Enzimatik A, dilakukan penambahan enzim papain. Enzimatik B, dilakukan penambahan enzim papain, deterjen SDS dan $\beta$-merkaptoetanol secara bersamaan. Enzimatik $C$, dilakukan penambahan deterjen SDS dan $\beta$ merkaptoetanol terlebih dahulu, setelah diinkubasi selama 24 jam dilakukan penambahan enzim papain. Proses inkubasi dilakukan selama 48 dan 96 jam, pada suhu $37^{\circ} \mathrm{C}$. Densitas karet dan kadar nitrogen total dari fraksi karet sebelum dan sesudah proses enzimatik dianalisis. Hasil penelitian menunjukkan bahwa kondisi optimal penurunan kadar nitrogen didapat pada kecepatan 19.000 rpm selama 60 menit (waktuinkubasi selama 96 jam) yaitu sebesar 88,26\% dengan kadar nitrogen total sebesar 0,05\% (menurundarikadar nitrogen awal $0,40 \%$ ) sertadensitasnyasebesar $0,8086 \mathrm{~g} / \mathrm{mL}$ (menurun dari densitas awal $0,9287 \mathrm{~g} / \mathrm{mL}$ ). Kadar nitrogen total sebelum sentrifugasi sebesar 0,40\%, dan setelah sentrifugasi sebesar 0,30\%. Densitas karet tanpa sentrifugasi, sesudah sentrifugasi pada kecepatan4.000 rpm dan sesudah proses enzimatik C masing-masing sebesar 0,9287; 0,8986 dan 0,8168 g/mL.Sedangkan untuk kecepatan $19.000 \mathrm{rpm}$, densitas karet tanpa sentrifugasi, setelah sentrifugasi dan setelah proses enzimatik C masing-masing sebesar 0,9287; 0,8890dan 0,8086 g/mL.

Kata kunci: Deproteinisasi Karet Alam, H. brasiliensis, Enzimatik

\begin{abstract}
Indonesia is the one of the biggest rubber producers, next to Thailand. Considering to the production of natural rubber, the culture of the plant of H. brasiliensis, is economically most important to tropical countries that produce rubber. One of the opportunities in latex production from rubber trees is to by producing low density natural rubber with low protein content, as the raw material for making sponge of floating pipe, rubber gloves, contraception's tool, and so on. The objective of this research was to produce natural rubber with low density and low nitrogen content, through centrifugation and deproteinization process by adding protease enzyme (papain,) and the mixture of denaturant ( $\beta$-merkaptoetanol and SDS) to rubber fraction of latex H. brasiliensis Muell Arg clone PR 255. Latex was centrifuged at $0^{\circ} \mathrm{C}$ with speed of 4,000 rpm for 180 minutes and 19,000 rpm for 60 minutes. Through the centrifugation, latex will be separated to three main fractions; they were the rubber fraction (on the top), $C$ serum (middle fraction), and lutoid particles as the bottom fraction. Later on, the rubber fraction was treated with papain and the mixture of papain and denaturant ( $\beta$-merkaptoetanol and SDS). Enzymatic A was the treatment for the addition ofthe proteolytic enzymes; Enzymatic B, was the treatment for the addition of papain enzyme which was added with denaturant simultaneously; and Enzymatic $C$, the treatment for the addition of papain enzyme anddenaturant, where denaturant was added into the rubber particle first, and then incubated for 24 hours and followed by adding the papain enzyme. Incubation process was done for 48 and 96 hours, at $37^{\circ}$. Density and total nitrogen content of
\end{abstract}


the rubber fraction before and after enzymatic process were analyzed. Results of the research showed that optimum condition for decreasing nitrogen content was reached on 19,000 rpm for 60 minutes centrifugation and 96 hours incubation, that was $88.26 \%$ with total nitrogen content of $0.05 \%$ and density of 0.8086 $\mathrm{g} / \mathrm{mL}$.Initial total nitrogen content before centrifugation was $0.40 \%$, and aftercentrifugationwas $0.30 \%$. The initial density of the rubber particle without centrifugation and density of the rubber particle after centrifugation at 4,000 rpmand after centrifugation of the enzymatic C were 0.9287, 0.8986 and $0.8168 \mathrm{~g} / \mathrm{mL}$, respectively. While for the velocity of 19,000 rpm, initial density of rubber without centrifugation, after centrifugation, and after enzymatic C process were $0.9287 \mathrm{~g} / \mathrm{mL}, 0.8890 \mathrm{~g} / \mathrm{mL}$ and $0.8086 \mathrm{~g} / \mathrm{mL}$, respectively.

Keywords: Deproteinization of Natural Rubber,H. brasiliensis, Enzymatic

\section{PENDAHULUAN}

Karet merupakan salah satu sumber daya alam hayati yang sangat potensial dan berlimpah di Indonesia. Keadaan alam Indonesia yang beriklim tropis menjadi wilayah yang strategis untuk tumbuhnya pohon karet. Pohon karet jenis $H$. brasiliensis adalah salah satu yang paling banyak ditanam di Indonesia dan tumbuh dengan subur (Shaw, 1997). Karet merupakan sumber devisa terbesar dari subsektor perkebunan di Indonesia dan telah diakui menjadi sumber keragaman hayati yang bermanfaat dalam pelestarian lingkungan serta memberikankontribusi bagi kesejahteraan rakyat dengan terbukanya lapangan usaha bagi masyarakat.

Produsen karet utama dunia didominasi negara Thailand, Indonesia dan Malaysia, dengan kontribusi masing-masing sebesar 33, 26, dan $13 \%$ dari total produksi karet dunia (Dradjat \& Nancy, 2000a; Wahyudi dkk., 2001). Indonesia memiliki areal tanaman karet terluas yaitu mencapai 3,28 juta ha yang tersebar di seluruh wilayah Indonesia (Indraty,2005). Diantaranya $85 \%$ merupakan perkebunan karet milik rakyat, dan hanya $7 \%$ perkebunan besar negara serta $8 \%$ perkebunan besar milik swasta (IRSG, 2004b). Sebagai salah satu negara produsen karet terbesar dan memiliki areal tanaman karet terluas, Indonesia berpotensi besar untuk menjadi produsen utama dalam masa mendatang. Potensi tersebut didukung dengan ketersediaan sumberdaya alam, tenaga kerja, teknologi maupun tenaga ahli. Indonesia perlu memanfaatkan peluang pengembangan industri karet dengan lebih baik, mulai dari perencanaan sampai dengan upaya menjaga agar tetap bertahan pada posisi sebagai lead country (Siswoputranto, 1981).

Karet merupakan kebutuhan yang penting bagi kehidupan manusia sehari-hari, hal ini terkait dengan mobilitas manusia dan barang yang memerlukan komponen yang terbuat dari karet seperti seperti ban kendaraan, conveyor belt, sabuk transmisi, dock fender, sepatu dan sandal karet (IRSG, 2004a). Produk-produk karet yang masih sepenuhnya diimpor adalah sarung tangan medis bebas protein alergen, alat kontrasepsi, dan pipa apung yang digunakan oleh beberapa industri seperti industri perminyakan untuk mengalirkan hasil pengeboran minyak lepas pantai ke kapal, atau industri pengerukan sebagai media untuk mengalirkan pasir, batu karang, dan air dari kapal keruk ke pantai.
Berdasarkan data dari BPPT pada tahun 2007 menginformasikan bahwa kebutuhan pipa apung Indonesia sekitar 4500 buah dengan biaya pengadaan sekitar 1,8 triliun rupiah. Padahal Indonesia merupakan salah satu negara penghasil karet terbesar di dunia, namun hampir $85 \%$ produk karet teknik yang digunakan berbagai industri dalam negeri masih diimpor. Salah satu karet teknik yang $100 \%$ masih diimpor adalah pipa apung. Indonesia perlu mengoptimalkan pemberdayaan karet alam yang didukung dengan manajeman dan teknologi yang lengkap, yang diperoleh melalui kegiatan penelitian dan pengembangan yang dibutuhkan. Dengan demikian biaya impor untuk bahan baku industri tersebut dapat diminimalkan.

Karet alam sebagai bahan baku memiliki keunggulan dibandingkan dengan karet sintetik yaitu harga yang lebih murah, memiliki daya elastisitas yang baik, daya tahan yang tinggi terhadap keretakan, daya tahan terhadap panas, dan memilikifleksibilitas serta plastisitas yang baik. Sifat fleksibilitas yang dihasilkan karena adanya kandungan fosfolipid (asam lemak) dan protein yang terikat pada kedua ujung struktur poliisopren/karet. Lateks $H$. brasiliensis merupakan cairan sitoplasma yang terdapat dalam semua pembuluh lateks pada seluruh bagian tanaman. Lateks biasanya berwarna putih kekuning-kuningan dan diambil dari lapisan kulit luarnya saja dimana pada bagian tersebut jumlah lateksnya lebih banyak. Berdasarkan penelitian yang dilakukan oleh Archer et al. (1969), bahwa didalam lateks selain terdapat komponen karet juga terkandung komponen bukan karet yang sangat penting, antara lain protein, karbohidrat, lipid, gula, dan air. Komponenkomponen bukan karet inilah yang membuat tingginya nilai densitas karet.Indonesia, merupakan negara tropis yang kaya akan tanaman budidaya yang cukup potensial, diantaranya adalah tanaman karet $H$. brasiliensis.

Sebagai produsen karet alam terbesar nomor dua di dunia, selayaknya kita harus dapat mencari klonklon karet unggul yang dapat menghasilkan lateks lebih banyak, melalui suatu penelitian yang intensif. Di dalam lateks terkandung protein-protein spesifik, khususnya yang terdapat di dalam partikel lutoid (bottom fraction) lateks. Protein-protein tersebut memiliki fungsi yang khusus dalam metabolisme aliran lateks. Protein utama yang terdapat pada partikel lateks dan mempengaruhi kuantitas lateks 
yang dihasilkan oleh suatu pohon karet adalah hevein. Selain memiliki sifat antifungal (Van Parijs $e t$ al., 1991), hevein juga merupakan protein yang dapat menjaga stabilitas koloidal lateks (Soedjanaatmadja et al., 1999). Dengan demikian, makin tinggi hevein yang terkandung dalam pohon karet klon tertentu, makin banyak lateks yang dihasilkannya (Soedjanaatmadja dkk., 1996; Soedjanaatmadja et al., 1999). Sedikitnya, ada enam protein mayor yang terdapat pada partikel lutoid lateks Hevea brasiliensis, yaitu protein $5 \mathrm{kDa}$ : hevein dan pseudohevein(Soedjanaatmadja et al., 1994), protein 14 dan $19 \mathrm{kDa}$ (Soedjanaatmadja, 1998), protein 29 dan $35 \mathrm{kDa}$ yaitu kitinase dan beta-glukanase (Subroto et al., 1996).

Protein-protein $19 \mathrm{kDa}, 29 \mathrm{kDa}$ dan $25 \mathrm{kDa}$ telah terbukti merupakan pathogenesis-related protein, yang bertanggungjawab sebagai sistem pertahanan pohon karet terhadap serangan dari luar (invasi virus patogen, jamur dan mikroorganisme lainnya). Dengan adanya protein-protein tersebut, pada proses penggumpalan (koagulasi) lateks sebagian akan terjebak dalam partikel karet sehingga inilah yang memungkinkan tingginya densitas karet alam hasil produksi pabrik. Selain tentunya dalam lateks itu sendiri terdapat komponen-komponen lain yang memiliki densitas tinggi seperti karbohidrat, asam amino bebas, asam nukleat, garam-garam anorganik dan ion-ion divalen (kalsium dan magnesium).

Menurut Cook \& Sekhar pada tahun 1953 dan Hemans \& Gills pada tahun 1948 (dalam Archer, 1959) menjelaskan bahwa lateks segar bila disentrifugasi pada kecepatan tertentu akan memisah menjadi tiga bagian utama, yaitu lapisan atas (fraksi karet) terdiri dari partikel-partikel hidrokarbon karet yang telah distabilkan oleh lapisan protein dan fosfolipid yang teradsorpsi; lapisan tengah (C-serum) mengandung zat-zat terlarut yang biasa terdapat dalam tanaman tingkat tinggi lain seperti asam amino, protein, karbohidrat, asam-asam organik, garam-garam anorganik dan nukleotida; serta lapisan bawah (lutoid) mengandung $12 \%$ padatan yang terdiri dari partikel-partikel lutoid. Penelitian akhirakhir ini menunjukkan bahwa karet alam yang dihasilkan oleh $H$. brasiliensis memiliki protein yang larut dalam lateks maupun protein yang berikatan dengan poliisopren, yang hampir semuanya dapat dihilangkan melalui deproteinisasi menggunakan enzim protease yang bersifat basa (Marinho \& Tanaka, 2000).Berbagai teknik proses produksi karet alam untuk menghasilkan karet alam yang bermutu tinggi telah banyak dilakukan, namun produksi karet alam densitas rendah melalui kombinasi proses sentrifugasi kecepatan tinggi dan reaksi enzimatik belum pernah dilakukan.Proses pemekatan lateks dengan cara ultrafiltrasi telah dilakukan oleh Veerasamy et al. (2003), dimana lateks pekat tersebut menghasilkan kadar karet kering sebesar $46 \%$, namun densitas dari karet alam yang dihasilkannya tidak diungkapkan. Dengan cara ini, protein yang teradsorpsi pada fraksi karet masih utuh dan tentu densitasnya pun masih cukup tinggi. Berdasarkan penelitian Marinho \& Tanaka (1999), pada partikel karet (pada setiap ujung struktur poliisoprena) yang terdapat pada lateks H.brasiliensis, teradsorpsi (terikat) molekul protein dan lipid, membentuk kompleks protein-poliisoprena-lipid, seperti yang terlihat pada Gambar 2.1 di bawah ini. Untuk membebaskan protein dari kompleks ini diperlukan proses proteolitik dengan enzim protease agar ikatan peptide dari protein tersebut putus. Sementara itu komponen lipidnya harus tetap utuh. Hal ini penting untuk menjaga agar fleksibilitas dari karet alam tetap terjaga.

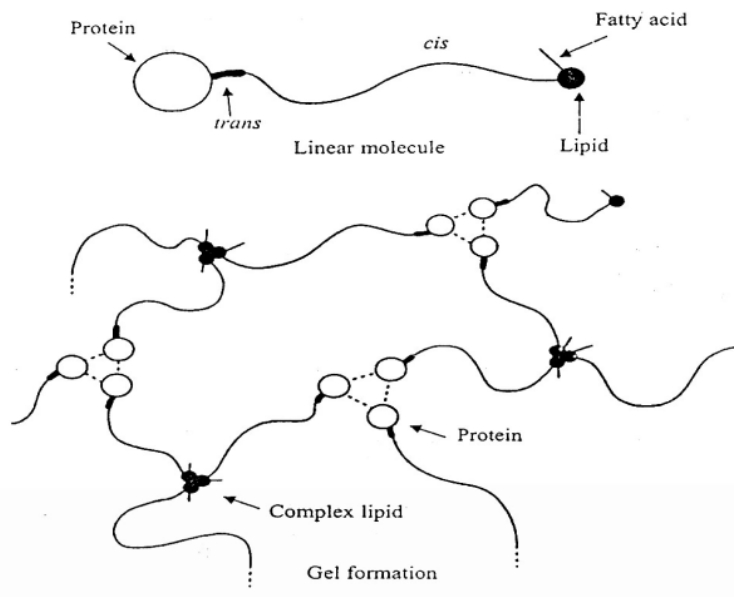

Gambar 1. Kompleks struktur protein-poliisoprena-lipid pada partikel karet alam dari Hevea brasiliensis (Marinho \& Tanaka, 1999)

Proses deproteinisasi lateks yang dilakukan oleh Eng et al. (1997) menunjukkan bahwa densitas karet alam tanpa deproteinisasi sedikit lebih tinggi dibandingkan dengan karet yang dideproteinisasi. Archer (1975) mengungkapkan bahwa pada proses deproteinisasi, agar lateks tidak menggumpal, lateks harus berada pada kondisi $\mathrm{pH}$ yang relatif tinggi (kondisi basa) untuk menjaga stabilitas koloidalnya. Dengan demikian maka enzim yang akan digunakan haruslah memiliki aktivitas maksimum pada kondisi basa tersebut. Berdasarkan penelitian dari Yapa \& Balasingham (1980) bahwa penambahan enzim proteolitik pada lateks $H$. brasiliensis akan memperpendek ikatan protein dan menjadikannya terlarut dalam air, sehingga dapat memisahkan protein dari karet. Yapa dan Balasingham juga melakukan proses deproteinisasi karet dengan menggunakan enzim papain (1974), dengan konsentrasi papain sekitar $0,05 \%$ yang ditambahkan langsung ke dalam lateks (tanpa proses sentrifugai terlebih dahulu). Kemudian dilakukan proses pengeringan. Karet yang diperoleh dalam bentuk krep atau balok dengan kandungan protein yang rendah. 
Namun tidak ada satupun contoh karet yang memiliki kadar nitrogen total yang lebih rendah dari $0,15 \%$.

Aik-Hwee et al. (1992) melakukan penelitian dengan FTIR untuk melihat struktur karet alam sebagai hasil pemurnian karet dari lateks dengan menambahkan enzim alkalase pada kondisi basa dan dilanjutkan dengan penambahan surfaktan. Hasilnya menunjukkan adanya pengurangan kandungan protein pada fraksi karet dari lateks tersebut.

Pada penelitian ini enzim protease yang digunakan adalah papain. Enzim papain didapat dari getah buah pepaya, selain murah dan mudah didapat, enzim papain efektif untuk proses deproteinasi. Detergen SDS akan mendenaturasi protein dengan mengubah struktur tiga dimensi protein dalam karet menjadi struktur yang lebih sederhana, sedangkan $\beta$ merkaptoetanol akan memutuskan ikatan disulfida (S-S) pada rantai polipeptida dengan cara mereduksi ikatan tersebut.

Klon karet yang dipilih pada penelitian ini ialah klon PR 255 yang merupakan salah satu klon unggul yang saat ini banyak ditanam di perkebunanperkebunan di Indonesia. Salah satu sifat unggul lateks $H$. brasiliensis Muell Arg. Klon PR 255 adalah dapat menghasilkan lebih banyak lateks dibandingkan dari klon jenis lain.

\section{BAHAN DAN METODE \\ Bahan penelitian}

Bahan utama yang digunakan pada penelitian ini adalah lateks segar yang diambil dari pohon karet $H$. brasiliensis Muell Arg. Klon PR 255 yang diperoleh dari perkebunan Gunung Hejo Purwakarta.

\section{Bahan kimia}

Bahan-bahan kimia yang digunakan adalah akuades, asam klorida, asam sulfat, BSA, TCA, dinatrium hidrogen fosfat, Folin Ciocalteu, glukosa, kalium sulfat, kupri sulfat pentahidrat, kasein, natrium hidroksida, natrium ditionit, natrium karbonat, natrium/kalium tartrat, amonium sulfat, $o$ Toluidin, indikator Toshiro, fenolftalein, $\beta$ merkaptoetanol dan deterjen SDS.

\section{Pengambilan contoh lateks segar}

Lateks $H$. brasiliensis segar disadap dari pohon karet klon PR 255 dan ditampung dalam wadah. Lateks ini diambil dari beberapa pohon karet dengan klon yang sama sampai diperoleh dua liter. Jika terbentuk gumpalan, gumpalan tersebut diambil dengan menggunakan spatula. Kemudian setelah ditampung dalam wadah ditambahkan natrium disulfit sampai konsentrasi $0,05 \% \mathrm{~b} / \mathrm{v}$, yang bertujuan untuk mencegah bekerjanya enzim polifenoloksidase. Selanjutnya wadah yang berisi lateks tersebut disimpan dalam ember yang berisi es untuk menjaga agar suhu tetap rendah dan lateks tetap segar. Untuk penentuan densitas lateks digunakan piknometer yang bersih dan kering kemudian ditimbang dan dicatat hasilnya sebagai massa piknometer kosong.

\section{Pemisahan fraksi-fraksi lateks dengan metode sentrifugasi}

Sentrifugasi dilakukan pada suhu $0^{\circ} \mathrm{C}$ dengan variasi kecepatan $19000 \mathrm{rpm}$ selama 60 menit dan 4000 rpm selama 180 menit. Dengan proses tersebut, akan terbentuk tiga fraksi utama, yaitu fraksi karet, fraksi tengah (C-serum), dan fraksi bawah (lutoid). Ketiga fraksi dipisahkan dan ditimbang massa masing-masing tiap fraksinya, lalu fraksi C-serum dan lutoid disimpan dalam botol dan dimasukkan dalam freezer selama seminggu. Setelah seminggu, fraksi karet yang terbentuk pada fraksi C-serum dan $\mathrm{B}$-serum dipisahkan dari lutoid dan C-serum.

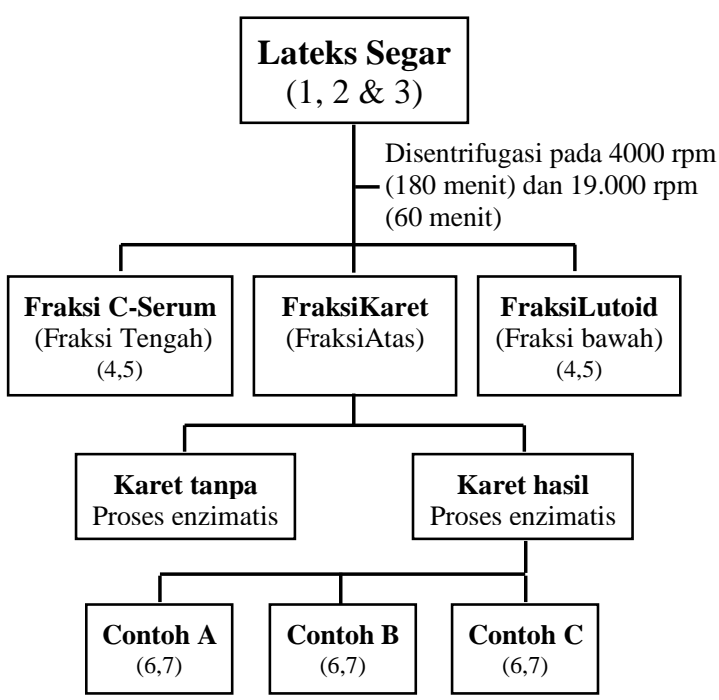

Gambar 1.Bagan alir prosedur deproteinisasi karet alam dari lateks $H$. brasiliensis Muell Arg. Klon PR 255 dengan cara sentrifugasi dan penambahan enzim papain serta deterjen SDS dan $\beta$-merkaptoetanol.

\section{Keterangan:}

1 : pengukuran densitas lateks dengan piknometer

2 : pengukuran $\mathrm{pH}$ lateks dengan $\mathrm{pHmeter}$

3 : pengukuran viskositas dengan metode Ostwald

4 : pengukuran kadar protein dengan metode Lowry

5 : pengukuran kadar karbohidrat dengan $o$-Toluidin

6 : pengukuran kadar nitrogen dengan metode Kjeldahl

7 : pengukuran densitas partikel karet dengan Sartorius densitymeter

\section{Pemisahan protein dankarbohidrat}

Cairan fraksi B-serum dan C-serum hasil sentrifugasi diambil sebanyak $1 \mathrm{~mL}$ kemudian ditambahkan dengan ammonium sulfat sampai kejenuhan $100 \%$ (sebanyak 0,767 gram), lalu disentrifugasi selama 30 menit dengan kecepatan $12000 \mathrm{rpm}$. Supernatan (karbohidrat) diuji dengan $o$ Toluidin sedangkan endapannya (protein) diuji dengan menggunakan metode Lowry.

Penentuan densitas karet dengan menggunakan Sartoriusdensitimeter dan Penentuan kadar 
protein (nitrogen total) pada partikel karet dengan metode Kjeldahl

\section{HASIL DAN PEMBAHASAN \\ PenentuanAktivitasEnzim}

Dari hasil percobaan diperoleh aktivitas enzim papainsebesar 12.000 unit/mL. Nilai ini menunjukkan bahwa enzim papain yang digunakan memiliki aktivitas yang tinggi sehingga dapat digunakan untuk memproteolisis protein yang terdapat dalam fraksi karet.

\section{PengambilanContohLateks Segar}

Proses pengambilan lateks segar dilakukan dengan cara penyadapan. Lateks segar yang diperoleh dimasukkan ke dalam botol yang berisi natrium bisulfit sampai konsentrasi $0,05 \% \mathrm{~b} / \mathrm{v}$, berfungsi sebagai anti oksidan dan anti koagulan. Natrium bisulfit akan mencegah bekerjanya enzim polifenoloksidase pada lateks segar, yang dapat menyebabkan lateks menggumpal. Botol yang berisi lateks ditutup rapat untuk mengurangi proses penggumpalan lateks dan mencegah masuknya air, udara dan pengotor-pengotor yang dapat menyebabkan terjadinya reaksi oksidasi pada lateks. Kemudian botol yang berisi lateks disimpan dalam ember yang berisi es agar lateks segar dan enzim polifenoloksidase tidak aktif bekerja.

\section{Penentuan Densitas Lateks Segar}

Densitas lateks segar ditentukan dengan menggunakan piknometer dan hasilnya digunakan sebagai data awal untuk dibandingkan dengan densitas karet hasil sentrifugasi dan proses enzimatik.

Dari hasil pengukuran diperoleh densitas lateks segar sebesar $0,9731 \mathrm{~g} / \mathrm{mL}$. Tingginya densitas awal lateks ini dikarenakan adanya senyawa yang memiliki densitas tinggi seperti protein, karbohidrat, lipid, dan senyawa organik pada karet. Setelah dilakukan pengeringan di dalam oven, densitas karet berkurang menjadi $0,9287 \mathrm{~g} / \mathrm{mL}$. Hal tersebut dikarenakan dengan prosespengeringan kandungan air dalam karet berkurang.

\section{Penentuan Viskositas Lateks Segar}

Penentuan viskositas lateks segarditentukan menggunakan alat viskometer Ostwald. Viskositas yang diperoleh dari hasil pengukuran dengan alat viskometer Ostwald sebesar 15,4842 Cp. Nilai ini lebih besar apabila dibandingkan dengan nilai viskositas air pada suhu yang sama, yaitu $0,8705 \mathrm{Cp}$. Hal ini disebabkan karena cairan lateks yang lebih kental dari air sehingga waktu alir lateks lebih lama dibandingkan waktu alir air akibat adanyakomponen seperti karbohidrat, protein, lemak, dan senyawa organik

\section{Penentuan pH Lateks Segar}

Penentuan $\mathrm{pH}$ lateks segar dilakukan dengan menggunakan alat $\mathrm{pH}$ meter. Dari hasil penelitian diperoleh $\mathrm{pH}$ lateks segar sebesar 6,92 Nilai ini menunjukkan bahwa lateks memiliki $\mathrm{pH}$ netral.

\section{Pemisahan Fraksi-Fraksi Lateks dengan Metode Sentrifugasi}

Pemisahan fraksi-fraksi lateks dilakukan dengan proses sentrifugasi. Proses ini bertujuan untuk memisahkan karet berdasarkan massa jenisnya. Partikel yang memiliki massa jenis tinggi seperti karbohidrat, protein, lipid, dan senyawa organik akan terdistribusi pada bagian bawah lateks sedangkan partikel yang memiliki massa jenis rendah seperti karet akan terdistribusi pada bagian atas lateks.

Pada penelitian ini, digunakan variasi kecepatan sentrifugasi yaitu $19.000 \mathrm{rpm}$ selama 60 menit dan kecepatan $4.000 \mathrm{rpm}$ selama 180 menit. Variasi kecepatan tersebut berdasarkan pada penelitian pendahuluan yang telah dilakukan sebelumnya dimana hal tersebut merupakan variasi kecepatan paling efektif untuk pemisahan fraksi dalam lateks. Kecepatan $4.000 \mathrm{rpm}$ dilakukan karena penelitian ini berorientasi untuk skala industri, dimana untuk volume lateks yang besar tidak memungkinkan untuk melakukan sentrifugasi pada kecepatan tinggi.

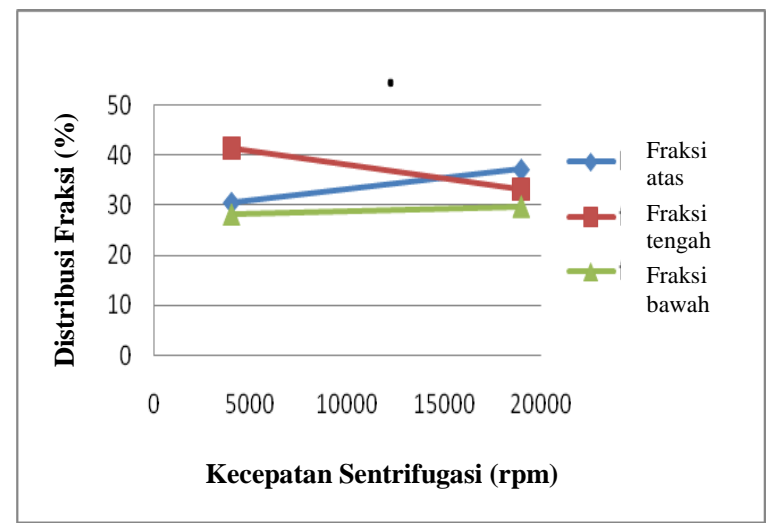

Gambar 2. Distribusi massa fraksi hasil sentrifugasi pada kecepatan $4.000 \mathrm{rpm}$ selama 180 menit dan $19.000 \mathrm{rpm}$ selama 60 menit.

Pada Gambar 2 di atas, menunjukkan bahwa setelah proses sentrifugasi akan diperoleh tiga fraksi utama yaitu fraksi atas (fraksi karet), fraksi tengah (C-serum), dan fraksi bawah (B-serum) dapat dilihat bahwa pada kecepatan 19.000 rpm selama 60 menit fraksi karet yang dihasilkan lebih banyak bila dibandingkan dengan kecepatan 4.000 rpm selama 180 menit. Hal tersebut menunjukkan bahwa semakin tinggi kecepatan sentrifugasi maka distribusi berat fraksi karet yang diperoleh semakin besar sedangkan berat dari fraksi tengah dan fraksi bawah semakin sedikit. Pada kecepatan 4.000 rpm selama 180 menit diperoleh fraksi tengah yang lebih besar.

Hal ini disebabkan karena masih terdapat fraksi karet yang terjebak di bagian tengah/tidak terdistribusi secara merata. 


\section{Perolehan Massa Karet Kering}

Setelah proses pengeringan dalam oven massa fraksi karet hasil sentrifugasi lebih rendah dibandingkan massa fraksi karet basah. Menurunnya massa karet tersebut disebabkan hilangnya kandungan air yang terdapat dalam fraksi karet. Data perolehan berat karet kering untuk kecepatan 4.000 rpm selama 180 menit dan kecepatan $19.000 \mathrm{rpm}$ selama 60 menit ditunjukkan pada Tabel 4.1.

Tabel 1. Perolehan massa karet kering fraksi karet hasil dari proses sentrifugasi dengan kecepatan $4.000 \mathrm{rpm}$ selama 180 menit dan kecepatan $19.000 \mathrm{rpm}$ selama 60 menit.

\begin{tabular}{|c|c|c|c|c|}
\hline \multicolumn{2}{|c|}{ Sentrifugasi } & \multicolumn{2}{|c|}{ Massa (g) } & \multirow[b]{2}{*}{$\begin{array}{c}\text { Presentase } \\
\text { Karet Total } \\
\quad(\%)\end{array}$} \\
\hline $\begin{array}{c}\text { Kecepatan } \\
\quad \text { (rpm) }\end{array}$ & $\begin{array}{r}\text { Waktu } \\
\text { (men) }\end{array}$ & Lateks & $\begin{array}{c}\text { Karet } \\
\text { Kering } \\
\text { Total } \\
\end{array}$ & \\
\hline 4.000 & 180 & 100 & 31,96 & 31,96 \\
\hline 19.000 & 60 & 100 & 33,37 & 33,37 \\
\hline
\end{tabular}

Selain terdapat pada fraksi atas (fraksi karet), partikel karet juga terdapat pada fraksi tengah dan fraksi bawah. Karet kering masing-masing fraksi kemudian dijumlahkan dan hasilnya dibandingkan dengan massa lateks awal, sehingga diperoleh persentase massa karet kering total pda setiap proses dan waktu sentrifugasi. Pada Tabel 2, persentase massa karet kering total yang diperoleh pada kecepatan sentrifugasi $19.000 \mathrm{rpm}$ selama 60 menit sebanding dengan kecepatan sentrifugasi $4.000 \mathrm{rpm}$ selama 180 menit.

Tabel 2. Persen total karet kering hasil sentrifugasi pada kecepatan 4.000 rpmselama 180 menit dan kecepatan $19.000 \mathrm{rpm}$ selama 60 menit.

\begin{tabular}{cccc}
\hline $\begin{array}{c}\text { Kecepatan } \\
\text { Sentrifugasi } \\
(\mathrm{rpm})\end{array}$ & $\begin{array}{c}\text { Waktu } \\
\text { Sentrifugasi } \\
\text { (menit) }\end{array}$ & $\begin{array}{c}\text { Massa } \\
\text { Karet } \\
\text { Kering } \\
\text { Total }(\mathrm{g})\end{array}$ & $\begin{array}{c}\text { Presentase } \\
\text { Karet Total } \\
(\%)\end{array}$ \\
\hline 4.000 & 180 & 31,96 & 31,96 \\
19.000 & 60 & 33,37 & 33,37 \\
\hline
\end{tabular}

\section{Penentuan Kadar Protein dengan metode Lowry}

Metode Lowry digunakan untuk menentukan kadar protein terlarut. Pada penelitian ini, kadar protein yang ditentukan yaitu kadar protein dari fraksi B-serum dan C-serum. Berbeda dengan fraksi karet yang menggunakan metode Kjedhal, hal ini dikarenakan kedua fraksi ini adalah cairan. Hasil yang diperoleh dapat digunakan sebagai perbandingan dengan kadar protein yang terdapat pada fraksi karet.

\section{Penentuan kadar karbohidrat dengan metode $o$ - Toluidin}

Penentuan kadar karbohidrat dilakukan pada fraksi tengah dan fraksi bawah lateks. Penentuan ini dilakukan pada fraksi tengah (C-serum) dan fraksi bawah (B-serum) untuk membuktikan bahwa dengan proses sentrifugasi akan mengakibatkan komponen dengan berat molekul tinggi akan terdistribusi pada bagian tengah dan bawah lateks.

Berdasarkan hasil penelitian, nilai kadar karbohidrat lebih tinggi pada kedua fraksi ini karena sama halnya dengan protein, komponen dengan berat molekul tinggi akan terdistribusi pada bagian tengah dan bawah lateks karena pengaruh gaya sentrifugal. Kadar karbohidrat pada fraksi bawah lebih rendah dibandingkan dengan fraksi tengah. Hal ini disebabkan karena dengan adanya proses sentrifugasi dan terpisah menjadi tiga fraksi, masih ada partikel karet yang terjebak pada fraksi C-serum dan Bserum. Pada saat partikel karet menggumpal, molekul karbohidrat ikut terjebak dalam kedua fraksi tersebut. Hal tersebut sesuai dengan tingginya nilai densitas karet pada kedua fraksi.

\section{Penentuan Densitas dan Kadar Nitrogen Total Karet Hasil Sentrifugasi}

Tujuan dari penelitian ini adalah untuk menghasilkan karet dengan densitas rendah dan kadar nitrogen total rendah. Proses sentrifugasi merupakan salah satu cara untuk menurunkan nilai densitas dan protein pada karet. Dalam penelitian ini, proses sentrifugasi dilakukan pada kecepatan $4.000 \mathrm{rpm}$ selama 180 menit dan $19.000 \mathrm{rpm}$ selama 60 menit. Melalui proses sentrifugasi, lateks akan terpisah berdasarkan massa jenisnya menjadi tiga fraksi utama yaitu fraksi atas (fraksi karet), fraksi tengah (Cserum), dan fraksi bawah (B-serum). Selama proses sentrifugasi berlangsung, komponen-komponen bukan karet yang memiliki berat jenis tinggi akan turun ke fraksi bawah sedangkan komponen karet yang memiliki berat jenis rendah akan naik ke fraksi atas.

Karet hasil sentrifugasi dan hasil proses enzimatik ditentukan densitasnya dengan alat sartorius densitymeter dan dibandingkan. Densitas yang diperoleh untuk karet tanpa proses sentrifugasi sebesar 0,9287 g/mL. Densitas awal karet ini sangat tinggi karena masih banyak protein dan senyawa lainnya yang masih terjebak dalam fraksi karet ketika karet masih menggumpal. Namun setelah dilakukan proses sentrifugasi maka densitas yang dihasilkan lebih rendah yaitu $0,8986 \mathrm{~g} / \mathrm{mL}$ untuk kecepatan sentrifugasi $4.000 \mathrm{rpm}$ selama 180 menit dan 0,8890 $\mathrm{g} / \mathrm{mL}$ untuk kecepatan 19.000 rpm selama 60 menit.

Untuk menentukan kadar nitrogen total fraksi karet digunakan metode Kjeldahl. Metode ini dipakai untuk menentukan kadar nitrogen dari sampel yang tidak larut atau berupa padatan. Pada metode Kjedhal, dilakukan melalui penentuan kadar nitrogen totalnya sehingga untuk memperoleh kadar proteinnya harus dilakukan dengan faktor konversi 5,7. Kadar nitrogen total yang diperoleh sebelum proses sentrifugasi sebesar $0,40 \%$, setelah proses sentrifugasi diperoleh $0,30 \%$ untuk kecepatan 4.000 rpm selama 180 menit dan kecepatan $19.000 \mathrm{rpm}$ selama 60 menit. Tingginya kadar nitrogen tersebut karena adanya komponen bukan karet. Dari hasil 
yang diperoleh hubungan antara besarnya densitas dengan keberadaan protein yang terjebak pada fraksi karet.Untuk menghasilkan kadar nitrogen yang lebih baik maka dilakukan proses enzimatik pada fraksi karet.

\section{Proses Deproteinisasi Secara Enzimatik Lateks Karet.}

Proses deproteinisasi bertujuan untuk menghilangkan protein yang teradsorpsi pada permukaan karet yang tidak bisa hilang melalui proses sentrifugasi karena protein tersebut berfungsi sebagai penstabil hidrokarbon karet.

Proses deproteinisasi secara enzimatik pada lateks karet hasil proses sentrifugasi dilakukan agar diperoleh kadar nitrogen total yang lebih rendah dari lateks hasil sentrifugasi. Pada penelitian dilakukan dengan tiga variasi enzimatik yaitu proses enzimatik A, enzimatik B, dan enzimatik $C$.

Proses enzimatik A dilakukan dengan penambahan enzim papain, lalu diinkubasi selama 48 dan 96 jam untuk mengoptimalkan kerja enzim papain dalam memproteolisis protein menjadi residu asam amino. Enzim papain merupakan golongan enzim protease yang berperan untuk memutuskan ikatan-ikatan-ikatan peptida yang terdapat pada protein yang terikat pada karet menjadi peptida pendek dan melarutkannya sehingga terpisah dari karet. Dengan putusnya ikatan peptida pada protein menyebabkan kandungan protein dalam hal ini kadar nitrogen dalam karet berkurang sehingga kadar nitrogen akan berkurang. Berkurangnya kadar nitrogen dalam karet akan menyebabkan berkurangnya densitas karet.

Penambahan deterjen SDS dan $\beta$-merkaptoetanol diharapkan dapat mempermudah kerja enzim papain untuk mengembangkan struktur tiga dimensi protein menjadi struktur yang lebih sederhana, sehingga enzim lebih mudah untuk memotong ikatan-ikatan peptida protein. Dari hasil penelitian, diperoleh kadar nitrogen total terendah pada contoh B sebesar $0,12 \%$ dengan nilai densitas sebesar $0,8407 \mathrm{~g} / \mathrm{mL}$ dari kecepatan 19.000 rpm dengan waktu inkubasi 96 jam. Penurunan kadar nitrogen total karet tanpa proses sentrifugasi sampai perlakuan contoh B ditunjukkan pada Tabel 3.

Tabel 3. Kadar nitrogen total dan densitas dari karet tanpa proses sentrifugasi, setelah proses sentrifugasi pada kecepatan 4.000 rpm selama 180 menit dan 19.000 selama 60 menit, contoh A, dan contoh B.

\begin{tabular}{|c|c|c|c|c|c|c|}
\hline \multirow{2}{*}{$\begin{array}{l}\text { Kecepatan } \\
\text { Sentrifugasi } \\
\quad(\mathrm{rpm})\end{array}$} & \multicolumn{4}{|c|}{ Kadar N-Total Karet (\%) } & \multirow{2}{*}{$\begin{array}{l}\text { Waktu Inkubasi } \\
\quad \text { (menit) }\end{array}$} & \multirow{2}{*}{$\begin{array}{c}\text { Densitas karet } \\
\text { Contoh B } \\
(\mathrm{g} / \mathrm{mL})\end{array}$} \\
\hline & $\begin{array}{c}\text { Tanpa } \\
\text { sentrifugasi }\end{array}$ & $\begin{array}{c}\text { Setelah } \\
\text { sentrifugasi }\end{array}$ & Contoh A & Contoh B & & \\
\hline \multirow{2}{*}{4.000} & \multirow{2}{*}{0,40} & \multirow{2}{*}{0,30} & \multirow{2}{*}{0,17} & \multirow{2}{*}{0,13} & 48 & 0,8482 \\
\hline & & & & & 96 & 0,8455 \\
\hline \multirow{2}{*}{19.000} & \multirow{2}{*}{0,40} & \multirow{2}{*}{0,30} & \multirow{2}{*}{0,16} & \multirow{2}{*}{0,05} & 48 & 0,8458 \\
\hline & & & & & 96 & 0,8407 \\
\hline
\end{tabular}

Dari hasil tersebut, penurunan kadar nitrogen total diikuti dengan penurunan densitas karet. Penurunan nilai densitas karet yang diperoleh dengan proses enzimatik B hanya sedikit jika dibandingkan dengan proses enzimatik A, yaitu sebesar $0,8482 \mathrm{~g} / \mathrm{mL}$ dengan waktu inkubasi 48 jam dan $0,8455 \mathrm{~g} / \mathrm{mL}$ dengan waktu inkubasi 96 jam untuk kecepatan $4.000 \mathrm{rpm}$ selama 180 menit dan 0,8458 $\mathrm{g} / \mathrm{mL}$ dengan waktu inkubasi 48 jam dan 0,8407 $\mathrm{g} / \mathrm{mL}$ dengan waktu inkubasi 96 jam untuk kecepatan $19.000 \mathrm{rpm}$ selama 60 menit. Penurunan densitas cukup besar disebabkan adanya $\beta$-merkaptoetanol dan detergen SDS sebagai denaturan yang membantu kerja enzim papain. Hasil tersebut menunjukkan penambahan denaturan cukup efektif dalam mempermudah kerja enzim memecah protein. Pada proses enzimatik B, kerja enzim papain kurang optimal karena deterjen SDS dan $\beta$-merkaptoetanol memiliki aktivitas yang tinggi dalam memecah protein. Denaturan ini tidak hanya mendenaturasi protein pada karet tetapi juga dapat mendenaturasi enzim papain yang juga merupakan protein.Supaya kerja enzim papain serta deterjen SDS dan $\beta$ merkaptoetanol lebih optimal, maka dalam penelitian ini dilakukan juga variasi contoh $\mathrm{C}$ (enzimatik $\mathrm{C}$ ). Dimana pada contoh $\mathrm{C}$, deterjen SDS dan $\beta$ merkaptoetanol ditambahkan terlebih dahulu ke dalam fraksi karet hasil sentrifugasi lalu diinkubasi selama 24 jam, kemudian ditambahkan enzim papain dan inkubasi selama 48 dan 96 jam. Penurunan kadar nitrogen total dan densitas dari karet awal sampai contoh C ditunjukkan pada Tabel 4.

Dari hasil penelitian menunjukan bahwa proses enzimatik $\mathrm{C}$ lebih efektif menurunkan kadar nitrogen total dan densitas karet dibandingkan dengan proses enzimatik B. Penurunan kadar nitrogen yang dihasilkan pada proses enzimatik $\mathrm{C}$ yaitu $0,05 \%$, sedangkan kadar nitrogen total yang diperoleh pada contoh B hanya mencapai nilai $0,12 \%$. Nilai densitas yang paling baik pada proses enzimatik $\mathrm{C}$ sebesar $0,8086 \mathrm{~g} / \mathrm{mL}$ diperoleh dari kecepatan $19.000 \mathrm{rpm}$ dengan waktu inkubasi 96 jam. Hal ini menunjukan bahwa dengan masuknya deterjen SDS dan $\beta$ merkaptoetanol terlebih dahulu ke dalam fraksi karet hasil sentrifugasi maka enzim papain akan lebih mudah memecah protein, karena protein sudah didenaturasi terebih dahulu oleh deterjen.Untuk melihat penurunan kadar nitrogen total dari karet 
awal sampai contoh $\mathrm{C}$ secara jelas ditunjukkan pada Gambar 3.

Tabel 4. Kadar nitrogen total dan densitas penurunannya dari tanpa proses sentrifugasi sampai dilakukan proses enzimatik pada contoh $\mathrm{C}$.

\begin{tabular}{|c|c|c|c|c|c|c|}
\hline \multirow{2}{*}{$\begin{array}{l}\text { Kecepatan } \\
\text { Sentrifugasi } \\
\text { (rpm) }\end{array}$} & \multicolumn{4}{|c|}{ Kadar N-Total Karet (\%) } & \multirow{2}{*}{$\begin{array}{l}\text { Waktu Inkubasi } \\
\quad \text { (menit) }\end{array}$} & \multirow{2}{*}{$\begin{array}{c}\text { Densitas karet } \\
\text { Contoh B } \\
(\mathrm{g} / \mathrm{mL})\end{array}$} \\
\hline & $\begin{array}{c}\text { Tanpa } \\
\text { sentrifugasi }\end{array}$ & $\begin{array}{c}\text { Setelah } \\
\text { sentrifugasi }\end{array}$ & Contoh A & Contoh B & & \\
\hline \multirow{2}{*}{4.000} & \multirow{2}{*}{0,40} & \multirow{2}{*}{0,30} & \multirow{2}{*}{0,17} & \multirow{2}{*}{0,06} & 48 & 0,8186 \\
\hline & & & & & 96 & 0,8168 \\
\hline \multirow{2}{*}{19.000} & \multirow{2}{*}{0,40} & \multirow{2}{*}{0,30} & \multirow{2}{*}{0,16} & \multirow{2}{*}{0,05} & 48 & 0,8127 \\
\hline & & & & & 96 & 0,8086 \\
\hline
\end{tabular}

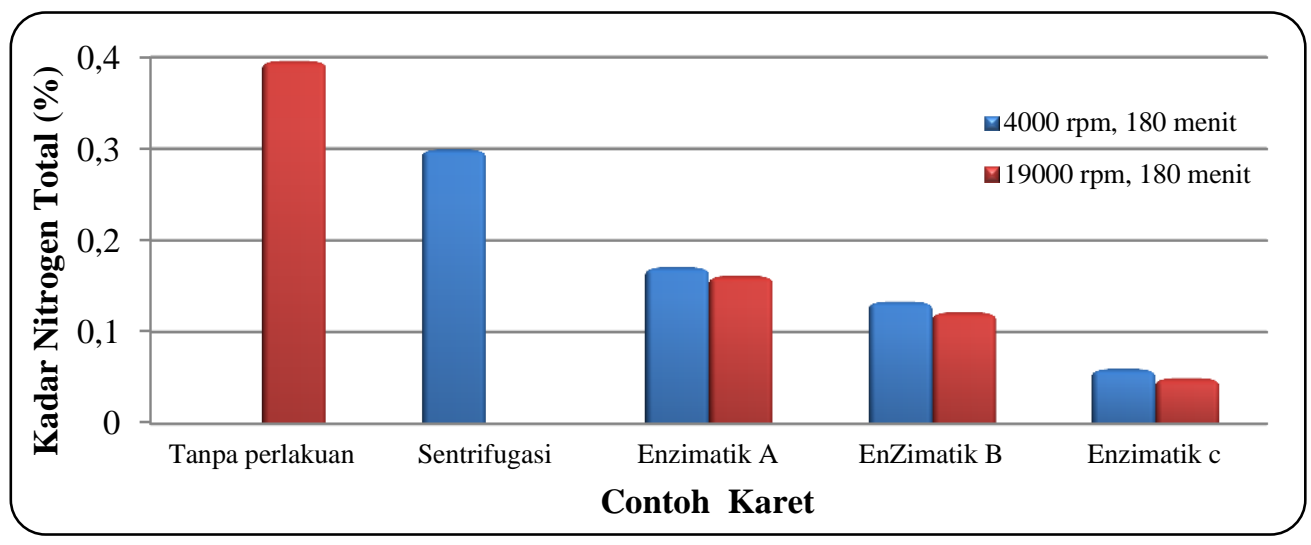

Gambar 3. Kadar nitrogen total karet tanpa perlakuan (1), setelah sentrifugasi pada kecepatan 4.000 rpm selama 180 menit dan kecepatan $19.000 \mathrm{rpm}$ selama 60 menit (2), karet dengan perlakuan enzim papain; enzimatik A (3), karet dengan perlakuan enzim dan denaturan; enzimatik B (4), dan perlakuan enzimatik C (5)untuk variasi inkubasi 48 jam.

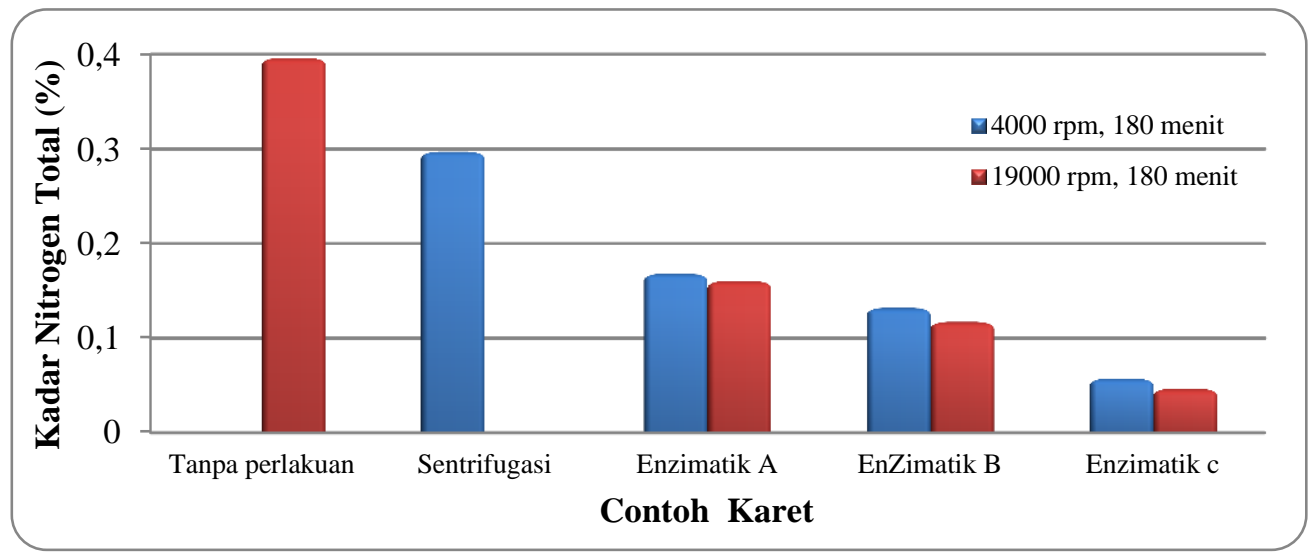

Gambar 4. Kadar nitrogen total karet tanpa perlakuan (1), setelah sentrifugasi pada kecepatan 4.000 rpm selama 180 menit dan kecepatan 19.000 rpm selama 60 menit (2), karet dengan perlakuan enzim papain; enzimatik A (3), karet dengan perlakuan enzim dan denaturan; enzimatik B (4), dan perlakuan enzimatik C (5)untuk variasi inkubasi 96 jam.

Pada Gambar 3 dan Gambar 4 menunjukkan bahwa pada setiap tahapan perlakuan mengalami penurunan kadar nitrogen total dimulai dari kadar nitrogen total karet awal tanpa proses sentrifugasi dan setelah dilakukan proses enzimatik pada contoh A, contoh B, dan contoh C. Kadar nitrogen total terendah dialami pada contoh $\mathrm{C}$ dengan kecepatan $19.000 \mathrm{rpm}$ dan waktu inkubasi 96 jam, dimana pada proses enzimatik ini penambahan deterjen SDS dan $\beta$-merkaptoetanol tidak dilakukan bersamaan dengan enzim papain, tetapi deterjen SDS dan $\beta$ merkaptoetanol ditambahkan terlebih dahulu untuk mendenaturasi protein karet dengan mengembangkan struktur protein yang awalnya merupakan bentuk kompleks tiga dimensi yang rumit menjadi bentuk yang lebih sederhana. Dengan adanya deterjen SDS 
yang berikatan secara hidrofobik dengan rantai asam amino dari protein maka struktur protein akan lebih mengembang, sedangkan $\beta$-merkaptoetanol akan memutuskan ikatan disulfida (S-S) pada rantai polipeptida dengan cara mereduksi ikatan tersebut, sehingga protein yang asalnya berbentuk tiga dimensi menjadi linier dan akan memudahkan enzim papain dalam memutuskan ikatan peptida pada protein.

Penurunan kadar nitrogen total pada karet akan diikuti oleh penurunan nilai densitas karet. Densitas karet yang diperoleh pada contoh $\mathrm{C}$ lebih rendah dibandingkan dengan densitas karet contoh $\mathrm{B}$ dan contoh A yang lebih rendah lagi bila dibandingkan dengan densitas karet hasil sentrifugasi. Penurunan densitas karet yang signifikan, dapat dilihat dari densitas karet awal tanpa proses sentrifugasi sampai densitas karet setelah dilakukan proses enzimatik contoh $\mathrm{A}$, contoh $\mathrm{B}$, dan contoh $\mathrm{C}$ ditunjukkan pada Gambar 5 dan Gambar 6.

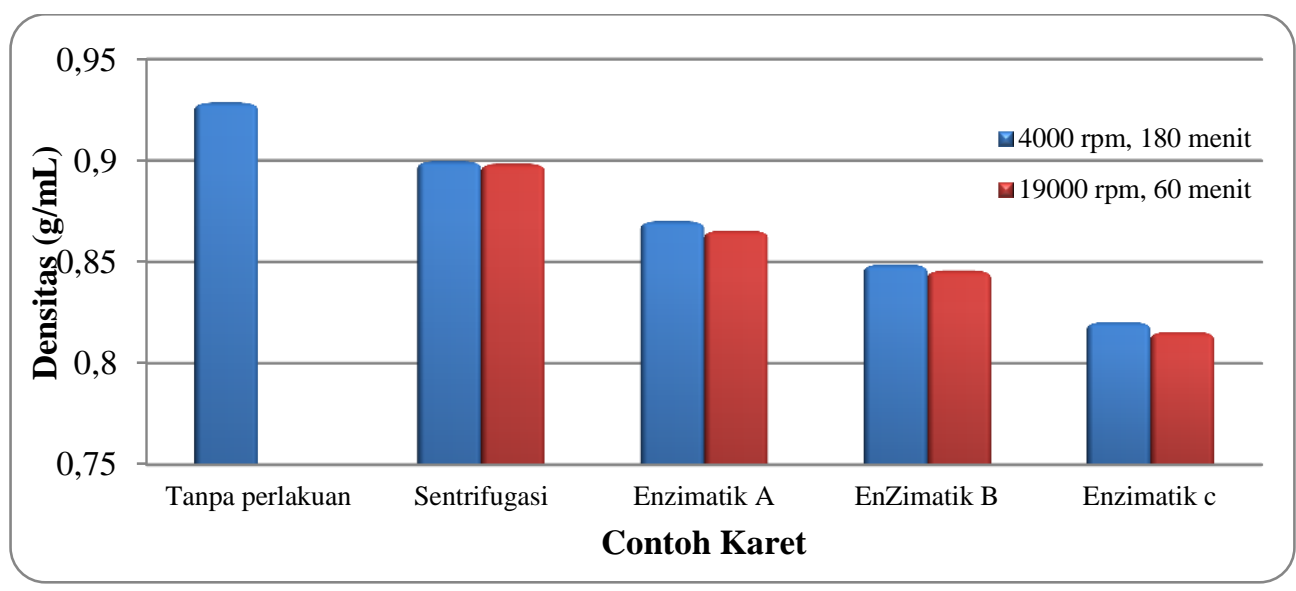

Gambar 5 Densitas karet tanpa perlakuan (1), setelah sentrifugasi pada kecepatan 4.000 rpm selama 180 menit dan kecepatan 19.000 rpm selama 60 menit (2), karet dengan perlakuan enzimik papain; enzimatik A (3), karet dengan perlakuan enzim dan denaturan; enzimatik B (4), dan perlakuan enzimatik C (5)untuk variasi inkubasi 48 jam.

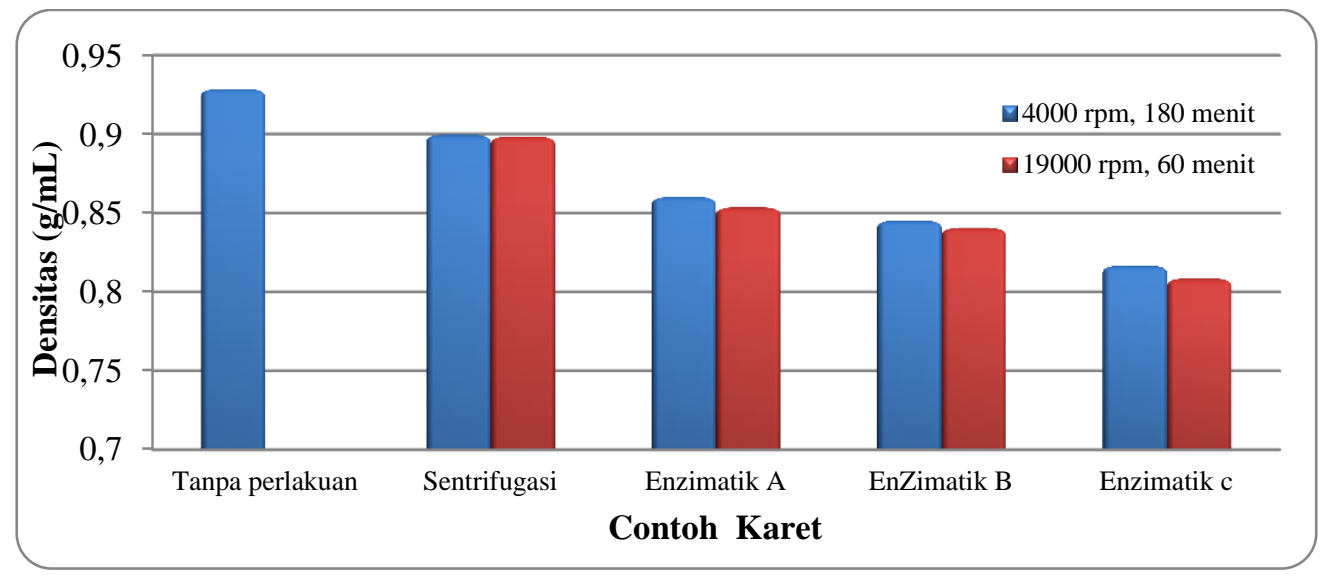

Gambar 6 Densitas karet tanpa perlakuan (1),setelah sentrifugasi pada kecepatan 4.000 rpm selama 180 menit dan kecepatan $19.000 \mathrm{rpm}$ selama 60 menit (2), karet dengan perlakuan enzimk papain; enzimatik A (3), karet dengan perlakuan enzim dan denaturan; enzimatik B (4), dan perlakuan enzimatik C (5)untuk variasi inkubasi 96 jam.

Pada'Gambar 6 menunjukkan bahwa densitas enzimatik C dengan waktu inkubasi 96 jam merupakan densitas terendah dengan nilai sebesar $0,8186 \mathrm{~g} / \mathrm{mL}$ untuk kecepatan sentrifugasi $4.000 \mathrm{rpm}$ selama 180 menit dan $0,8086 \mathrm{~g} / \mathrm{mL}$ untuk kecepatan $19.000 \mathrm{rpm}$ selama 60 menit. Dimana pada karet tanpa perlakuan diperoleh densitas sebesar 0,9287 $\mathrm{g} / \mathrm{mL}$, setelah sentrifugasi $19.000 \mathrm{rpm}$ selama 60 menit sebesar $0,8986 \mathrm{~g} / \mathrm{mL}$ setelah proses enzimatik pada contoh A sebesar $0,8537 \mathrm{~g} / \mathrm{mL}$ dan contoh B sebesar 0,8407 g/mL.Nilai densitas tersebut sesuai dengan kadar nitrogen total yang diperoleh. Hasil penelitian menunjukkan bahwa deterjen SDS dan $\beta$ - 
merkaptoetanol lebih efektif jika ditambahkan tidak bersamaan dengan enzim papain.

Hasil penelitian menunjukkan bahwa untuk memperoleh suatu karet dengan kadar nitrogen total dan densitas yang rendah dapat dilakukan dengan cara penambahan $\beta$-merkaptoetanol dan detergen SDS terlebih dahulu kedalam fraksi karet hasil sentrifugasi lalu diinkubasi selama 24 jam, kemudian ditambahkan enzim papain, diinkubasi selama 48dan 96 jam. Proses sentrifugasi skala laboratorium digunakan variasi kecepatan $19.000 \mathrm{rpm}$ selama 60 menit, sedangkan untuk skala industri dapat digunakan pada kecepatan yang lebih rendah $4.000 \mathrm{rpm}$, namun memerlukan waktu sentrifugasi yang lebih lama yaitu selama 180 menit.

\section{DAFTAR PUSTAKA}

Archer, B.L., B.G. Audley, Mc Sweeney and T.C. Hong. (1969). Studies on composition of latex and bottom fraction particles. J. Rubb. Res. Inst. Malaya, 21(4): 560-569.

Archer, B.L., (1975). Biochemistry of enzymic deproteinisation of hevea latex. Proc. Int. Rubb. Conf. Kualalumpur, 2: 532-542.

Aik-Hwee, E.Y. Tanaka. and G. Seng-Neon. (1992) FITR studies on amino groups in purified hevea rubber. J. Nat. Rubb. Res, 7(2): 152-155.

Eng, A.H., Y, Tanaka and S.N, Gan. (1997). Some properties of epoxidised deproteinised natural rubber, J. nat. Rubb. Res. 12(2): 82-89.

Marinho, J.R.D. and Y. Tanaka. (1999). Structural characterization of wild rubber: gel content. $J$. Rubb. Res., 2(4): 231-238.

Rozeboom, H.J., A. Budiani, J.J. Beintema and B.W. Dijkstra. (1990). Crystallization of hevamine.An enzyme with lysozime and chitinase activity from Hevea brasiliensis. Res. Report. Bioson, RUGNetherlands.

Silalahi, A., U.M.S. Soedjanaatmadja, S. Soemitro and J.J. Beintema. (2003). Isolation of protease active at neutral $\mathrm{pH}$ with Molecular Mass of 65 $\mathrm{kDa}$ from lutoid body fraction of Hevea brasiliensis latex, Journal Rubber Research, 69(1): 48-57.

Soedjanaatmadja, U.M.S. (1991). Isolasi dan karakterisasi Hevein dari Bottom Fraction Lateks Hevea brasiliensis Klon GT-I dan LCB-1320. Tesis S-2. Institut Teknologi Bandung.
Soedjanaatmadja, U.M.S., J. Hofsteenge, J.J. Beintema, C.M.J. Stratingh and A.P Bruin. (1994). Demonstration by Mass Spectrometry that pseudohevein and hevein have ragged $\mathrm{C}$ terminal sequences. Biochim, et Biophys. Acta.1209: 144-148.

Soedjanaatmadja, U.M.S., T. Subroto and J.J. Beintema. (1995). The effluent of natural rubber factories is enriched in the antifungal protein hevein. Bioresource Technology, 53: 39-41.

Soedjanaatmadja, U.M.S., T. Subroto, and J.J. Beintema. (1995). Processed product of the hevein Precursor in the latex of the rubber tree (Hevea brasiliensis). FEBS Letter Journal, 363: 211-213.

Soedjanaatmadja, U.M.S. (1998). Struktur Hevein dan Pseudohevein serta Proses Pembentukan Hevein di Dalam Lateks Hevea brasiliensis Muell Arg. Disertasi-S3. Institut Teknologi Bandung.

Soedjanaatmadja, U.M.S., T. Subroto, J.J. Beintema and S. Soedigdo. (1999). Does hevein stabilize or destabilize rubber latex?. Journal Rubber Research, 2(2): 69-77.

Subroto, T., G. Van Koningsveld, H.A. Schreuder, U.M.S. Soedjanaatmadja and J.J. Beintema. (1996). Chitinase and beta-1,3-glucanase in the lutoid-body fraction of Hevea brasiliensis Latex. Phytochemistry, 43: 29-37.

Subroto, T., Henk de Vries, J.J. Schuringa, U.M.S. Soedjanaatmadja, J.Hofsteenge, P.A. Jekel and J.J. Beintema. (2001). Enzymic and structural studies on processed proteins from the vacuolar (lutoid-body) fraction of Hevea brasiliensis Latex. Plant Physiol. Biochem. Journal, 39: 1047-1055.

Van Parijs, J., W.F. Broekaert, I.J. Goldstein and W.J. Pneumans. (1991). An antifungal protein from rubber tree (Hevea brasiliensis), Planta, 183: 258264.

Veerasamy, D., N.M. Sulaiman, J. Nambiar and Y. Aziz. (2003). Concentration of natural rubber (NR) field latex using tubular cross flow ultrafiltration system, Journal Rubber Research, 12-35.

Yapa, P.A. and S.I. Senanayake. (1980). Use of papain treatment in the manufacture of deproteinized natural rubber, J. Rubb. Res Inst. Srilangka, 29-32 